\title{
Directed - Project Based Learning (DPjBL) as a language learning model to improve students' english achievement
}

\author{
Tri Pratiwi ${ }^{1}$, Sufyarma Marsidin ${ }^{2}$, Hermawati Syarif $^{3}$, Yahya $^{4}$ \\ ${ }^{1}$ Universitas Muhammadiyyah Sumatera Barat, Padang - Indonesia, \\ (triepratiwi28@yahoo.com) \\ 234 Universitas Negeri Padang - Indonesia, (sufyarma.marsidin_mc@yahoo.co.id)
}

\begin{abstract}
This research aimed to improve students' English achievement by developing learning model in English subject for VIII graders of SMP N 1 Uram Jaya through Directed-Project Based Learning (DPjBL) implementation. This study is designed in Research and Development (R \& D) using ADDIE model development. Test instrument for finding out the effectiveness of DPjBL and also students English achievement which were then analyzed quantitatively by using T-test. The results showed that DPjBL is effective to use, it is seen from the difference in value between the pretest and post-test of the control class and the experimental class. From the results of a questionnaire filled in general, the students and teachers agreed to DPjBL learning model. The practicality of teacher book got 93.3 and the practicality of students book got 97.0. It shows that DPjBL is an effective learning model and this learning model can increase the students' English achievement.
\end{abstract}

Keywords: learning model, english achievement, directed-project based learning (DPjBL)

\section{Introduction}

As a English teacher, we know that the less optimal outcomes of English learning is a matter that frequently arises from a learning process (Madya, 2004). From the results of the needs analysis (preliminary analysis) the researcher obtained data from the Director of Primary and Secondary Education of Lebong Regency related to the score distribution of National Exam (UNAS) in Bengkulu Province where in the academic year 2016/2017 it was known that Lebong Regency ranked lowest for all subjects tested in national exam with average score of 170.28 and English subject in Lebong Regency even got the worst score of 41.19 among other areas, which decreased when compared with the last year score of 41.87 from the minimum passing grade of 6.00 . It means that more than $59 \%$ of students did not reach the minimum passing grade among the National Exam participants of 1,684 students. This has already happened from 2015 to 2017 where the National Exam in Lebong Regency always ranked lowest. Besides, the outcome of English as national exam subject at SMP N 1 Uram Jaya was the lowest in Lebong Regency by 36. 37, going down from the last year score of 38.75 under the minimum passing grade of 6.00 . 
To boost the outcomes of students' learning in case of English subjects, teachers have applied some learning models in the classroom, one of which is project-based learning model. However, after the teachers had implemented it for one semester, this project-based learning (PjBL) model did not generate any significant changes. Thus, the teachers no longer use PBL model in English learning process. To find out where the students' weaknesses in learning English, the researcher gave a questionnaire to students of VIII grade and also conducted an interview session. There were 118 students of VIII grade of SMP N 1 Uram Jaya divided into 5 classes. The researcher took 25 students to attend the interview session as well as to fill in a questionnaire. The followings are the student questionnaire results.

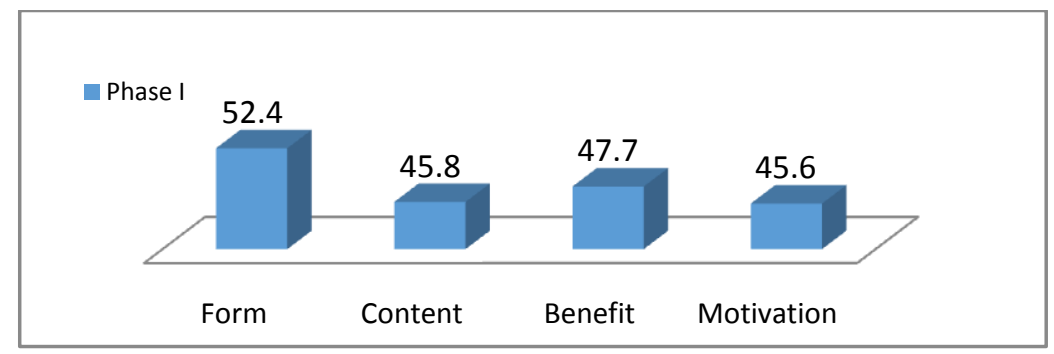

Figure 1 Students' Perception of DPjBL

The above chart indicates that students' perception of PjBL model were very low where only $52.4 \%$ of students perceived this PjBL model was attractive. $45.8 \%$ of students stated the contents of this PjBL model were relevant to the material taught. Only $47.7 \%$ of students considered this PBL model were useful for English learning and finally about $45.6 \%$ of students said this PjBL model could motivate students in learning English. Thus, it can be concluded that the project-based learning model $(\mathrm{PjBL})$ is in desperate need of development so it would be suitable for students' need and can increase the outcomes of students' learning, especially for English.

Regarding the results of field observations and interviews, students stated that Project Based Learning (PjBL) model was a bit hard to apply because it required high independence and discipline in running PjBL model activities in accordance with actual procedures. Seeing that the students' attitude is still far from independence and discipline, then the learning must run under the teachers' guidance or direction.

From the field facts found above, the researcher is interested in conducting research and development of project-based learning (PjBL) model. The development performed by the researcher is to design a Directed - Project Based Learning or here in after referred to as DPjBL. Sholihatin (2011) has proven research on the success of improving student achievement in the learning process with directed learning model and published her scientific research results as the improvement of student achievement using active learning method using directed teaching model, where previously the students' average scores were 60, 93 but after implementing the directed teaching model, the students' average scores increased significantly to 78.37 .

The DPjBL can be described as follows:

1. Modeling by the Teacher. At this stage the teacher will explain the theme, topic or object to be the material of project designing activities, as well as provide samples of products students will have, so that students can directly observe samples of products they work on.

2. Observation. Teacher asks the students to observe the subject matter individually. The teacher also encourages students to look for information on topics either through the handbook or other media.

3. Get an Idea (Stated the Problem). The learning process begins with an essential question that is a question that can assign students to perform an activity. The topic taken must be relevant, in line with the real-world reality and begins with an in-depth investigation. The teacher directs students with questions till they understand the topic or theme they will work on. 
4. Choose the Alternative Solution. This phase is to make collaborative planning between teacher and students so that students feel the "sense of belonging" to project planned. This plan contains the rules of the game, taking the supporting activities in answering essential questions, integrating the various subjects that may be the alternative of solution later.

5. Design The Project. In this phase, the teacher and students build collaboration. Teacher prepares for materials and tools in line with the theme of the project to do. Then the teacher asks the students to design the project related to the tools and materials provided. Teacher and students revise the project together, but the project depends on students' decision, the teacher simply directs them to focus on the theme.

6. Steps of Implementation. In this stage, teacher and students (1) make project completion timelines, (2) make project completion deadlines, (3) directs students to plan steps to undertake, (4) guides students when they make unrelated project steps, and (5) requests students to make an explanation or reason for project selection.

7. Reflection. Students reflect both individually and in groups. At this stage, teacher and students develop discussions in order to improve the performance already designed so that in the end they find a new finding to answer the essential question made.

8. Do the Project (Experiment the Project). At this stage, students undertake or work on projects that have been previously designed, in groups. Teacher will notice students co-operation, in case of debate, the teacher will assess how students figure out the solutions. Teacher is monitoring as long as the students complete the project. Teacher may keep an eye by facilitating students in each process and serves as a mentor for each student activity. Teacher may arrange a rubric that records all important student activities to facilitate the monitoring process.

9. Exhibit The Project (Presentation Results of the Project). At this stage, students will present the products manufactured in group to reconstruct or build new comprehensive knowledge for all learners.

10. Assessment. Teacher makes an assessment to measure standard achievement, evaluates each student's progress, provide feedback on the level of student understanding that has been achieved, and help teacher to develop further learning strategies. At the end of the learning process, the teacher will appreciate the product that the students have completed.

DPjBL is a model developed to bridge between conventional learning ingrained deeply in every learning activity in the classroom and DPjBL learning. In this DPjBL model, students will feel flexible because the learning method does not change drastically but step by step. It will make students independent in every learning activity in the classroom. Even this DPjBL model will prepare students' mental and skill if the schools apply the 2013 curriculum as a whole that encourages students to be independent, disciplined and competitive.

\section{Method}

This is the Research and Development Research (Borg \& Gall 1983). In this research the development model in use is ADDIE. The concepts of ADDIE model stand for Analysis, Design, Development, Implementation and Evaluation (Robert Maribe Branch, 2009: 2).

This research was conducted at SMP N 1 Uram Jaya Lebong Regency academic year 2016/2017 in VIII grade students on English subjects. The data were collected by interview, observation, questionnaire, test, and documentation.

There are two data analysis techniques in this study, including qualitative and quantitative data analysis (Miles \& Hubermen, 1992). While quantitative data analysis technique analyzes Validity, Reliability, and Practicality. Specifically for analyzing the effectiveness of learning as a reflection of learning quality, it uses experimental research with the type of "Pretest-Posttest Control Group 
Design". The outcomes of students' learning are considered effective when students reach a minimum score of 65.

\section{Result and Discussion}

The results of preliminary analysis on the condition of English learning at this Junior High School showed that the current condition of learning either the teachers' condition or the school, curriculum, students, infrastructure condition and government policy especially in education still require further improvement, correction and special attention especially for English learning management related to the teachers' ability and necessary infrastructure facilities.

The process of DPjBL development model may include the initial design of the English learning model planning, then media, material and evaluation experts validate the initial product design. The product validation average result was 4.78 from the maximum value of 5.00, indicating that it was strongly valid, and can be used in the implementation stage.

Before conducting research, the teacher distributed the questionnaires on the students' perceptions feasibility test on PBL model to students and after research, the teacher provided questionnaires of students' perceptions feasibility test on the developed PBL model called DPjBL. The comparison of students' perception feasibility test results is given as follows.

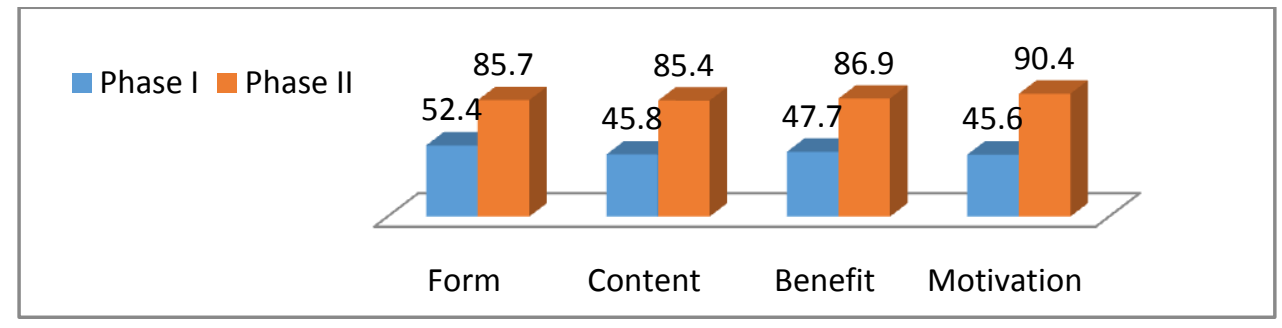

Figure 2 Comparison Result of Students' Perception of DPjBL

The charts above showed those students' perceptions on the developed model were significant in which the $85.7 \%$ of students agreed that the form of DPjBL model was very interesting; $85.4 \%$ of students stated that the content of the DPjBL model was awfully appropriate and effective for English learning; $86.9 \%$ of students also argued that this DPjBL model provided enormous benefits in the English learning process. Finally, around $90.4 \%$ of students said that they had high motivate onto learn English using this DPjBL model.

The result of students' book product practicality was also fairly high at 4.85 or $97.0 \%$ of students approved the use of DPjBL book in English learning process. And the result of teacher's book product practicality was also high at 4.67 or $93.3 \%$ of teachers stated that teacher's book product was very effective in English learning process.

The last is the results of t-test calculation, suggesting that student's English learning outcomes increased significantly. The following chart presented the comparison between pre-test and post-test results as well as t-test results. 


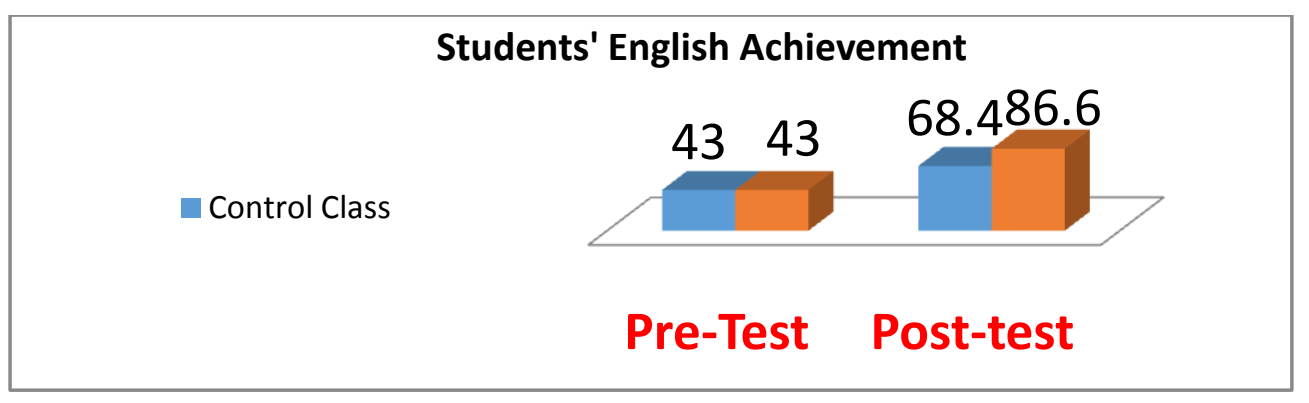

Figure 3 Students' English Achievement

\begin{tabular}{|c|c|c|c|c|c|}
\hline \multirow[b]{3}{*}{ Score } & \multicolumn{5}{|c|}{ Tabel 1. Group Statistics } \\
\hline & Class & $\mathbf{N}$ & Mean & Std. Deviation & Std. Error Mean \\
\hline & Experimental Class & 25 & 86,4400 & 5,90254 & 1,18051 \\
\hline $\mathrm{s}$ & Control Class & 25 & 68,4000 & 6,87992 & 1,37598 \\
\hline
\end{tabular}

Table 2. Result of T-test

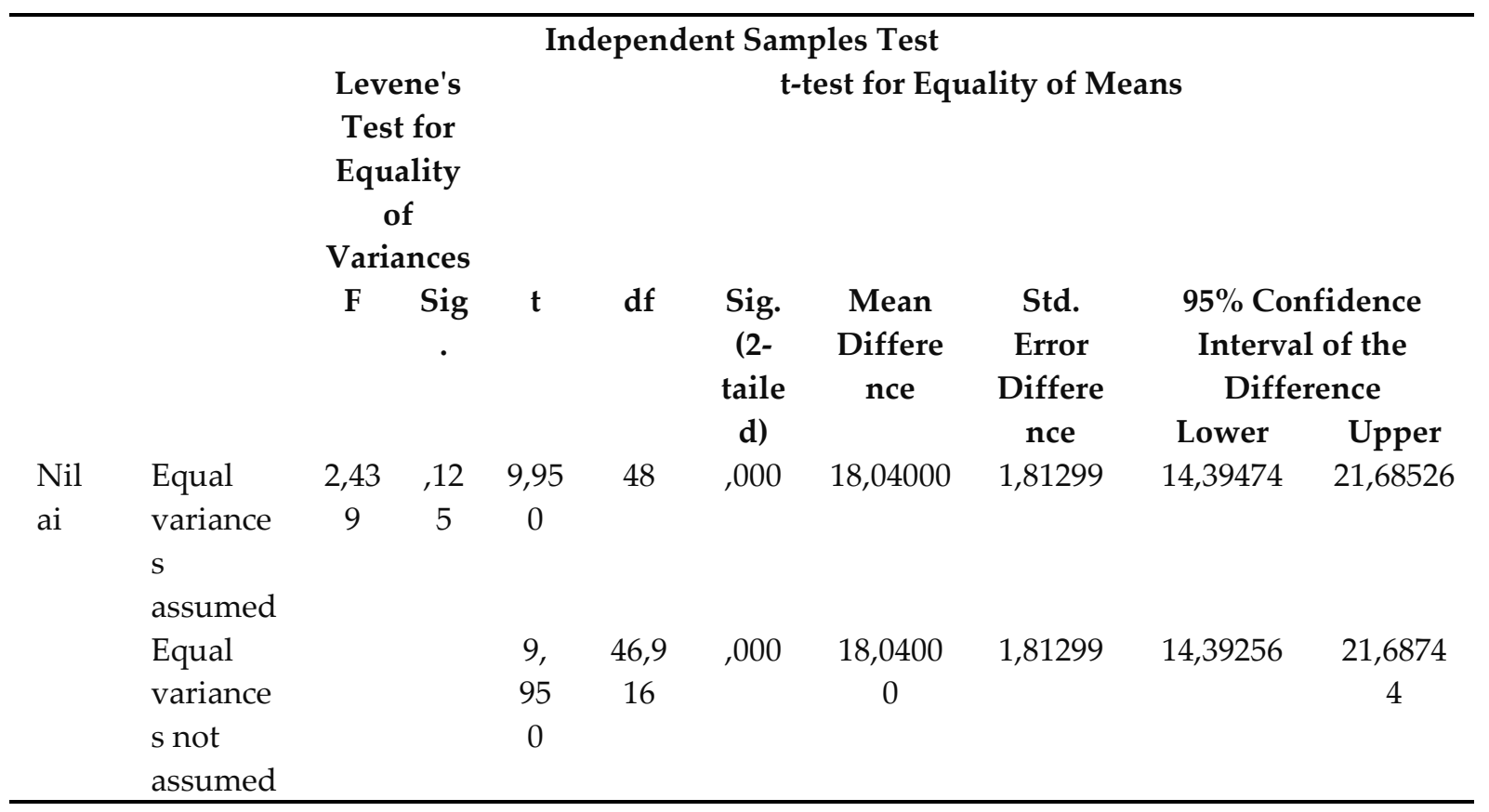

From the above chart, the researcher found that the post-test difference between the control and experimental classes was 68.4 for the control class and 86.6 for the experimental class. The t-test above also demonstrated that the value of sig. (2-tailed) of $0.000<0.05$, in short, it concluded that the DPjBL model is more effective than conventional learning.

\section{Conclusion}

Based on research objectives and explanation of the results obtained in research on DPjBL model development, it can be concluded as follows; product of DPjBL model development is feasible to use in English learning at SMP Negeri 1 Uram Jaya. The evaluation results of English learning material experts, learning model designers, teacher assessment, and students' assessment proved that DPjBL model is effectively applied in English learning at SMP Negeri 1 Uram Jaya. This is known from the increase in evaluation results at the post-test stage. 
From the results of questionnaire filled in, students generally agreed with DPjBL learning model. This learning model can increase the motivation to learn, grow self-esteem, courage to express opinions, and appropriate for the students' character.

\section{Acknowledgments}

This research was supported/partially supported by SMP N 1 Uram Jaya and Dinas Pendidikan Kabupaten Lebong. I thank to my promotors Prof. Dr. Sufyarma Marsidin, M. Pd, Prof. Dr. Hermawati Syarif, M. Pd, Dr. Yahya, M. Pd for comments that greatly improved this research. I thank to my colleagues who provided insight and expertise that greatly assisted the research. I would also like to show my gratitude to the validators, headmaster and teacher of SMP N 1 Uram Jaya for sharing their pearls of wisdom with me during the course of this research.

\section{References}

Borg, W. R., \& Gall, M. D. (1989). Educational research. An introduction (5th ed.). White Plains, NY: Longman

Branch, Robert Maribe. (2009). Instructional Design: The ADDIE Approach. New York: Springer Science \& Business Media, LLC.

Madya, Suwarsih. (2004). Sosok sejati guru bahasa Inggris belum muncul. Harian Kompas, p.8

Miles, Matthew B dan Huberman, A Michael. (1992). Analisis Data Kualitatif. Jakarta: Universitas Indonesia Press

Sholihatin. (2011). Penerapan Active Learning Dengan Model Pengajaran Terarah Dalam Meningkatkan Prestasi Belajar Mata Pelajaran Ips Kelas Ii Mi Sunan Ampel Bangeran Dawarblandong Mojokerto. Unpublished master's thesis, UIN Sunan Ampel Surabaya 